\title{
CROSS-CULTURAL COMPETENCE IN THE TIME OF CROSS-BORDER MIGRATION
}

\author{
Laviniu BOJOR \\ “Nicolae Bălcescu"Land Forces Academy, Sibiu, Romania \\ laviniu.bojor@yahoo.com
}

\begin{abstract}
The waves of migrants that are trying to escape from the violence of their home state become a real threat for the security environment of the European countries. Our national security forces, like police and army personnel, should take into consideration future missions that consist in face to face interrelation actions with people from other cultures. Achieving knowledge and developing cross-cultural interrelation skills, with the help of which we can overcome some barriers in communication, can make the difference as long as the force power, in its entirety, no longer represents the sole and sufficient condition to solve actual multicultural crises situations.
\end{abstract}

Keywords: migration, cross-cultural communication, cultural identities interrelation, social integration.

\section{Introduction}

The conflict in Syria continues to be, by far, the main reason for which more than 1 million refugees have crossed Europe's borders during 2015. The estimates issued by the International Organization for Migration show that the majority of them, approximately 1.011 .000 migrants [1], crossed the Mediterranean Sea and about 34.900 migrants reached the heart of Europe on land, having crossed Turkey and Albania. Almost half of them, about 476.000 people were able to arrive and seek asylum in Germany but many were forced to stop in the countries through which they transited Europe like Greece, Italy or Hungary. As noted by some military analysts, "for the first time in its history, the international migration affects all the EU Member States, turning them into countries of immigration"'[2] although only certain states, highly developed, were targeted as the terminus of the waves of immigrants. A good example in this respect is the case of our neighbours in Hungary who, despite having closed their borders with Croatia, currently need to manage the largest number of migrants related to the local population, due to approximately 177,000 people who have remained on our neighbours' territory in 2015. The waves of migrants from the Middle East did not stop even in winter, despite the harsh conditions that endanger the crossing of the Mediterranean Sea and, since the conflict in Syria has worsened, the number of those who will seek asylum in the bosom of Europe will certainly increase in the near future. Besides the problems caused by the financial effort required for hosting the migrants, or the polemics between the European Union (EU) member states regarding the acceptance of the migrants' resettlement [3], their integration within the local communities becomes a big challenge for the government authorities of the EU Member States. 


\section{Aspects on Integrating Economic Migrants in Europe}

In the recent decades, strongly economically developed nations, like France and the United Kingdon, were faced with the migration of large numbers of people in search of better paid jobs, willing to permanently settle down in countries with a better living standard than in those where they came from.

Accepting within the European countries the Moroccans, the Turks, the Albanians and other so-called economic asylum seekers, mostly Muslim, therefore with a cultural heritage totally different from the values practiced within the European community, was done according to certain economic opportunities, such as opening the labour market to cheap human resources or developing the economy by increasing further investment.

However the information on the planning of recent terrorist attacks inside certain closed enclaves, or subsequently hiding the terrorists inside the Muslimmajority areas, make us to study in detail the means in which these economic migrants are integrated within the European communities. Soeren Kern, an analyst at the Gatestone Institute, ever since 2011, has been drawing the attention on the formation of Muslim enclaves within the EU through a so-called "occupation without tanks or soldiers" [4]. Referring to "the multicultural policy", this generator of electoral votes and public opinion support, as the primary factor of the development of micro-states governed by Sharia, he outlines the areas prohibited to non-Muslims ("NO GO ZONES") formed within the most developed European countries.

In the United Kingdom, the "Muslims against Crusades" group aims to create autonomous enclaves, subject to Sharia and outside the English law, in Northeast and East of London and in cities such as Birmingham, Bradford, Derby, Dewsbury, Leeds, Leicester, Liverpool, Luton, Manchester and Sheffield.
The problems Kern identified in these sensitive areas in England are very serious and include:

- death threats against women who do not wear the Islamic headscarf;

- banners with pro Muslim inscriptions and intimidating threats against nonMuslims such as "You are entering a SHARIA controlled zone"

- vandalizing advertising billboards that contradict the teachings of the Koran;

- " the ethnic cleansing" by harassing nonMuslims in the predominantly Muslim neighbourhoods, such as Bury Park/Luton, in order to compel them to move to other areas of the city.

These actions, isolated and rare in the first stage, have become so common nowadays that the local population in a suburb of London nicknamed the preachers the Tower Hamlets Talibans and those territories the Islamic Republic of Tower Hamlets.

In France, no less than 751 "Sensitive Urban Zones"(ZUS - "Zones urbaines sensibles"), where more than 5 million Muslims live, were identified and marked on maps by the French police and pictured on official government sites. The actions that show that the French state does not exercise full control over these areas include:

- the closure of roads in cities such as Paris, Lyon, Marseille and Toulouse by the Muslim population, for the celebration of certain religious activities;

- the use of amplifiers (loudspeakers and audio stations) for broadcasting sermons and prayers;

- the police authorities' refusal to intervene within these zones to avoid any Muslim riots.

In Belgium there are whole areas where the police are often attacked when carrying out a search activity, and its capital, Brussels, is $20 \%$ Muslim. In the Kuregem district the police use light armoured equipment during patrols and in 
the Molenbeek neighbourhood the police are not allowed to eat or drink in public during the Ramadan.

In Germany, a police commissioner said that, although the authorities deny this fact, there are whole neighbourhoods where the police cannot patrol in small teams or without armoured equipment or even that it cannot provide security in certain prohibited zones.

Neither Italy has escaped the problems caused by the integration of Muslims into the civilian society. On certain days, they have ceased control over the Venice Square in Rome for their street prayers or raised threats to destroy the San Pietronio cathedral in Bologna, which contains a six-century-old fresco inspired by Dante's Inferno, which depicts a Muhammad tortured by the demons in Hell.

In the Netherlands, a court of law asked the government to publish the list of the 40 prohibited zones due to the problems caused by the majority Muslim population. The districts where the biggest problems occur are: Kolentik (Amsterdam), Pendrecht, Het Oude Noorden and Bloemhof (Rotterdam), Ondiep (Utrecht), Rivierenwijk (Deventer) Spangen (Rotterdam), Oude Westen (Rotterdam), Heechterp/Schieringen (Leeuwarden) and Noord-Oost (Maastricht).

The acceptance and the permissiveness of laws attracted like a magnet the Muslim immigrants in Sweden's major cities, where they currently represent $25 \%$ of the total population. The creation of enclaves has resulted in the occurrence of the prohibited zones where the fire fighters or the ambulances refuse to enter without police escort. This behaviour is caused by previous incidents such as:

- the attack on the fire fighters during an intervention to put out a fire at the mosque in Malmo;

- the Molotov cocktail attacks on the police by young Muslims in the city of Goteborg;

- the destruction of 15 police cars in
Angered district;

- the attacks on ambulances and fire trucks in the Backa neighbourhood in Goteborg.

The assertion of Imam Adly Abu Hajar of Malmo that "Sweden is the best Islamic state in the world" certainly conveys the true intentions of the Muslims in the region.

\section{Challenges Raised by the Integration of Migrants in the European Community Member States}

Currently, to these reasons for accepting and integrating migrants related to economic justifications, another one is added, of a social nature: the aging of the European population. This demographic problem that Europe is facing can be solved by accepting waves of migrants mostly made up of young people aged between 16 and 30 years old. But these benefits, be them economic (access to cheap human resources) or social (the rejuvenation of the population), depend on the way in which the integration of immigrants in the labour market and in the European society is done, as they are facing two major challenges: the existing legislative limitations and the intercultural relationship between the refugees and the local population.

Regarding the current regulations, they can be amended if the international, national, regional and local authorities prove flexibility and make decisions which will solve specific problems such as:

- the enactment and enforcement of standardized legal provisions on the status of the migrants within the European community, which are based on refugee protection regulations, first approved in 1951 in Geneva. Their implementation will lead to equally and correctly treating the migrants and to their acceptance irrespective of religion or country of origin.

- the cancellation of the access visas or the minimum periods of residence in a state without legal documents; 
- the supplementation of personnel to conduct specific security checks;

- the allocation of funds necessary for accommodating and feeding all those seeking the refugee status;

- the reassessment of the procedures for obtaining the refugee documents and their simplification, if necessary;

- the provision of the support required to easily go through the procedures for obtaining the legal employment papers (information points, assistance in filling out forms, provision of translation services, classes for learning the national language or English, training or specialization courses depending on each individual's education, etc.);

- the protection offered to minors and to persons needing help due to age or health problems;

The second challenge, more sensitive and harder to solve, is the socio-cultural integration of the immigrants within the local communities of the host countries. In order to prevent the emergence of Muslim enclaves and the insecurity arising from these "NO GO ZONES", the European states' authorities must act in this direction which is specific to intercultural diversity.

The first issue to be tackled is the development of intercultural competences of the immigrants but also of the security forces representatives (border guards, gendarmes and police) and of the members of the population who come in direct contact with them.

Intercultural competence training is done through education, by developing certain qualities and a behaviour that allows us to "survive" in a world that is becoming increasingly multicultural. Through intercultural education we come to accept cultural diversity, to promote the values of "the other", and, most importantly, to seek dialogue and acceptance to the detriment of divergences and isolation. The acceptance of the migrants must, first of all, continue the open-mindedness promoted up to now by the EU within which the national identities are not lost but highlighted and cultures do not clash, but complement each other.

But this is only possible if the culture of the Muslim partners is not a threat to our own identity and the examples above on the formation of the enclaves in the European cities show that we cannot allow a social integration that allows the existence of certain zones which are prohibited to persons of another religion.

For this relationship to be lasting, the first contact is extremely important, and the local authorities should develop educational programs implying the mandatory attendance of the members of the security forces and of the entities engaged in relating with the migrants, such as: personnel of the social assistance and labour force management offices, health care staff, humanitarian organizations or volunteers involved in the integration of migrants, and so on.

During these programs, those involved in the direct relationship with people coming from a different cultural environment, will develop cognitive skills (knowledge and understanding of the social system and the values promoted by "the other") and interpersonal skills (communication and interaction with "the foreigner").

It is not only about acquiring knowledge on the culture of the migrants but it also includes issues on "adapting" the behaviour in order to mitigate those "invisible differences represented by expectations, values, goals and styles of communication that bring along cultural differences and make them be misconstrued as a personal violation of trust or respect"'[5].

This relating process is based on the human being, which makes it extremely complex and impossible to standardize by finding universal rules that once applied will lead to the same result. Communication between people is actually a constant negotiation in which each party tries to 
reach an agreement based on personal interest or on the social entity that they represent.

The migrants get in contact with the border guard forces that were sent to the border crossing points to stop their access to certain countries. The mission of the security forces is based on political decisions and economic reasons such as avoiding agglomeration in some countries (as it is currently the case with everyone wanting to get to Germany) and the even distribution towards regions or countries that can absorb this influx of migrants. Lack of communication between the two parties will lead to incidents or even violence by the use of the provided equipment, facts that cannot lay the foundations of a lasting relationship.

Communication involves knowledge of the situation as it includes a permanent exchange of messages, either verbal or nonverbal, and good negotiation happens only if it rests on good information. Informing the migrants on the consequences of overcrowding the transit centres in Germany (such as lack of accommodation, lack of funding and, most importantly, the impossibility of integrating such a large number of migrants in the employment system of a single state), would certainly lead to the migrants' mobilization and their accepting the alternatives to be redistributed to countries which are less developed but able to offer them integration into the civil society.

A defiant attitude, the use of shields and batons, tear gases or even lethal weapons by the security forces in order to make the waves of migrants return home is not a real solution because these people have "bought" a one-way ticket, and returning to their native places marked by wars and insecurity is not an option. At least not a real one. This aggressive behaviour that we have identified not only from representatives of the security forces but also from journalists, is the first step in establishing a long-term collaboration, whether we want it or not.

\section{Applying Negotiation Techniques in Relating with the Migrants}

Taking into consideration this aspect and the lack of experience on intercultural communication of the national authorities from the EU member states, the implementation of these intercultural education programs should require those who come into contact with the migrants to use negotiation techniques such as:

- the use of a representative by which to ensure the success of the negotiations due to the involvement of people who have social, intercultural and communication skills. Using those who have previously settled in the EU countries and who can easily overcome cultural differences or language difficulties;

- the accommodation technique which means creating a climate of trust, getting to know the interlocutors and only then proceeding to the negotiation of terms and conditions.

- the admiration technique can be implemented to highlight the benefits of a healthy democratic regime, based on the Constitution, guarantor of individual rights and freedoms, as opposed to an authoritarian one, marked by the fanaticism of the dictators and based on the laws of Sharia. There are many suspicions concerning the infiltration of members or collaborators of the ISIS terrorist groups among the migrants. This technique along with others such as "providing alternatives" (arguing the opportunity to live in a stability environment) or the technique "this is what you lose" (making migrants aware of the fact that the possible clues regarding the collaboration with terrorist groups will automatically result in their expulsion from the EU) can lead to their giving up on earlier plans to conduct or accept attacks within the European states;

- the elusion technique can be used when wanting to avoid to conduct actual negotiations or when it takes time to find a 
better solution;

- the communion of interests aims at negotiations achieving common interests and the best integration into a new society is getting a job. In Romania there are currently corporations which, due to labour shortages, provide transport for their employees from distances more than $50 \mathrm{~km}$ away from the work place. The existence of these opportunities should be identified and included in the negotiation with the migrants as they serve common interests;

- the association technique is aimed at joining in the initial steps to achieve specific objectives. Even if some real solutions to the existing problems have been identified, in most cases it needs joint efforts to achieve them. The access to wellpaid jobs is conditioned by attending training courses or by learning an international language;

- the dissociation appears when the involvement in specific projects is not desired or when the undertaken actions are incompatible with the values promoted within the EU. The best example is the dissociation from this intention to form zones prohibited to the non-Muslims in cities or neighbourhoods where implementing Sharia law is desired;

- the static game consists in intoxicating the interlocutor with real statistical data to impress him and make him give up alternatives that do not meet our own goal;

- the good faith technique relies on the psychological effect created by granting trust that the person can carry out the specific project or, in reverse, when the migrant is assured that we will accomplish the assumed obligations;

- the small steps technique is performed by obtaining immediate benefits that may go unnoticed, but will ultimately achieve the desired goal;

- the inciting technique consists in appealing to the partner's ego in order to achieve the objectives;

- the tolerance technique is applied by avoiding challenges or delaying the response based on the first impulse;

- the surprise technique is to change the methods or the approach in order to confirm some assumptions;

- the fait accomplished technique is used to test the standpoint of the interlocutor who is brought into a critical situation;

- the resignation technique consists in convincing the person you are talking to that you have given up on achieving a goal but in reality you keep the situation under control;

- the hand-over technique can be used when certain advantages are handed over to the interlocutor, either because they cannot be achieved or when you want this gesture to win you other benefits;

- the time pressure occurs when acting out of time or when there is a deadline;

- the bazaar technique is specific to Eastern traders that begin with high initial prices so that they could subsequently fall to the actual value of the product.

Regardless of the technique used, the negotiation between the EU representatives and the migrants should aim to achieve winwin results, and, if it is not possible, then it must focus on partially achieving goals to set up a fair and lasting relationship with those who will become our neighbours in the near future.

\section{Conclusions}

Managing the waves of Muslim migrants who keep on striking on the borders of the European continent must be a priority of the government authorities in all countries, whether or not these countries are targeted by those fleeing the failed states of the Middle East. The example of Germany who appointed the head of the German Labour Agency, Frank Jürgen Weise, also the director of the German Federal Office for Migration and Refugees is to be followed by the other governmental authorities because he understood the importance of finding solutions for the integration of the migrants which will also solve internal issues caused by the labour 
shortages in certain industries. But these economic measures must be complemented by the social ones, avoiding the formation of enclaves and Muslim-majority zones within which tensions grow and frustrations accumulate due to the felt sense of rejection. Training skills for intercultural communication and for accepting "the foreigners" is the only viable solution for a real integration of the migrants and these qualities can only be achieved through intercultural education. Going through specific programs will help participants, be they migrants or representatives of the local communities, to communicate effectively and to negotiate their objectives where appropriate, to put aside their egos or their cultural prejudices and not to focus on the differences but rather on building bridges. Without these efforts to integrate the Muslims within the democratic societies based on the rule of law, we can state that we are witnessing today an invasion that does not use weapons, tanks or soldiers but mass migration of followers to the step by step Islamization of the old European continent.

\section{References}

[1] http://www.bbc.com/news/world-europe-34131911

[2] Raţiu Aurelian, Ameninţări şi factori de risc la adresa securităţii globale, "Nicolae Bălcescu" Land Forces Academy Publishing House, Sibiu, 2016, p. 51.

[3] The BBC uses the term migrant to refer to all people on the move who have yet to complete the legal process of claiming asylum. This group includes people fleeing wartorn countries such as Syria, who are likely to be granted refugee status, as well as people who are seeking jobs and better lives, who governments are likely to rule are economic migrants.

[4] Soeren Kern, European „NO GO” Zones for Non Muslims Proliferating, accessed on 3rd April 2016 on the website www.gatestoneinstitute.org/2367/european-muslim-no-gozones

[5] Cosma M., Cosma B, „Educaţia interculturală, de la teorie la practică”, „Lucian Blaga” Publishing House, Sibiu, 2006, pp. 184-185. 